\title{
EFEITO DA INTERAÇÃO ENTRE CARVÃO ATIVADO E N'-BENZILAMINOPURINA NA PROPAGAÇÃO IN VITRO DE BANANEIRA, CV. GRAND NAINE (AAA) ${ }^{1}$
}

\author{
FREDERICO HENRIQUE DA SILVA COSTA², JONNY EVERSON SCHERWINSKI PEREIRA ${ }^{3}$, \\ MARIA APARECIDA ALVES PEREIRA ${ }^{4}$, JANIFFE PERES DE OLIVEIRA ${ }^{4}$
}

\begin{abstract}
RESUMO - O carvão ativado possui a propriedade de adsorver os compostos fenólicos liberados pela oxidação dos tecidos lesionados durante o cultivo in vitro. O objetivo deste trabalho foi avaliar os efeitos da interação entre o carvão ativado e diferentes concentrações de $\mathrm{N}^{6}{ }_{-}$ benzilaminopurina (BAP) na multiplicação in vitro da bananeira, cv. Grande Naine (AAA). O meio de cultura utilizado foi o MS, solidificado com 5 g. $\mathrm{L}^{-1}$ de ágar. O cultivo foi mantido em sala de crescimento a $25 \pm 2^{\circ} \mathrm{C}$, fotoperíodo de 16 horas e intensidade luminosa de $30 \mu \mathrm{mol} . \mathrm{m}^{-2} \mathrm{~s}^{-1}$. Foram avaliadas a presença e a ausência de carvão ativado $\left(0\right.$ e 3 g.. $\left.\mathrm{L}^{-1}\right)$ e quatro concentrações de BAP $\left(0 ; 2 ; 4\right.$ e 6 mg. $\left.\mathrm{L}^{-1}\right)$ no meio de cultura. O delineamento foi inteiramente casualizado, com cinco repetições, em um sistema fatorial $2 \times 4$. Os explantes foram avaliados a cada 30 dias, por um período de quatro subcultivos. Após cada subcultivo, o comprimento de brotações, a taxa de multiplicação, o vigor, o nível de oxidação das brotações emitidas e o número de raízes formadas foram avaliados. Independentemente das concentrações de BAP, o carvão ativado influenciou significativamente em todas as variáveis analisadas. De maneira geral, a adição de carvão ativado afetou negativamente a taxa de multiplicação, embora tenha melhorado o vigor e o número de raízes e diminuído a oxidação dos explantes. Na ausência de carvão ativado, o BAP proporcionou as maiores taxas de multiplicação das brotações.
\end{abstract}

Termos de indexação: Musa sp., micropropagação, compostos fenólicos, oxidação, citocinina.

\section{INTERACTION EFFECT BETWEEN ACTIVATED CHARCOAL AND N6-BENZYLAMINOPURINE IN THE IN VITRO PROPAGATION OF BANANA, CULTIVAR GRAND NAINE (AAA)}

\begin{abstract}
Active charcoal has the capacity to fix phenolic compounds released by the oxidation of manipulated tissues during in vitro cultivation. The present work objective was to evaluate the interaction effects between active charcoal, combined to different BAP concentrations in the in vitro banana propagation, cv. Grand Nain (AAA). The culture medium used was the MS, solidified with $5 \mathrm{~g} . \mathrm{L}^{-1}$ agar. Cultures were kept in a growth room at $25 \pm 2^{\circ} \mathrm{C}$ with a photoperiod of $16 \mathrm{~h}$ at $30 \mu \mathrm{mol} . \mathrm{m}^{-2} \mathrm{~s}^{-1}$. It was evaluated the presence and the absence of active charcoal $(0$ and $\left.3 \mathrm{~g} . \mathrm{L}^{-1}\right)$ and different concentrations of BAP $\left(0,2,4\right.$ and $\left.6 \mathrm{mg} . \mathrm{L}^{-1}\right)$ in the culture medium of four subcultures at four-week intervals. The experimental design was completely randomized in a $2 \times 4$ factorial scheme, and five replicas. After each subculture shoot height, multiplication rate, vigor, oxidation level and number of roots per shoot were evaluated. Independently of BAP concentrations, active charcoal had influenced significantly on the results. In general, the addition of active charcoal affected negatively the multiplication rate, while it improved the vigor, root number and decreased the oxidation level of the shoots. In the absence of activated charcoal, BAP provided larger multiplication rates of shoots. Index terms: Musa sp., micropropagation, phenolic compounds, oxidation, citokinin.
\end{abstract}

\section{INTRODUÇÃO}

O cultivo de brotos meristemáticos de bananeira em laboratório tem apresentado crescimento nos últimos 30 anos, sendo que esta técnica vem sendo adotada em diversos países como alternativa à propagação convencional de material vegetal de genótipos superiores (Gübbük \& Pekmezci, 2004). Isso se deve ao fato de esta técnica apresentar diversas vantagens ao método comumente utilizado para obtenção de mudas, tais como alta taxa de multiplicação, uniformidade fisiológica dos materiais, disponibilidade de propágulos livres de doenças durante o ano inteiro, rápida difusão de novas variedades, uniformidade de brotos, entre outras (Arias, 1992). Contudo, há ainda alguns fatores que limitam em parte o processo de micropropagação de algumas cultivares de bananeira e que interferem principalmente na taxa de multiplicação, entre os quais, a alta taxa de oxidação dos explantes (Oliveira et al., 2001), a qual é caracterizada pelo escurecimento das partes excisadas dos explantes e do meio de cultivo, influenciando na absorção dos constituintes do meio pelo explante em virtude da obstrução do tecido oxidado. Tal oxidação é resultante da liberação de compostos fenólicos in vitro, precursores da síntese de lignina pelo tecido injuriado (Van Winkle et al., 2003). Esse acúmulo de polifenóis e produtos de oxidação, como melanina, suberina, lignina, cutina e calose em torno da superfície excisada, modifica a composição do meio de cultivo e, conseqüentemente, a absorção de metabólitos (Andrade et al., 2000). Os compostos fenólicos sofrem oxidação pelas enzimas polifenases, produzindo substâncias tóxicas que normalmente inibem o crescimento dos explantes, ocasionando, não raramente, até a morte dos mesmos (Sato et al., 2001). Aliado a este fato, existe a necessidade de se otimizarem os níveis exógenos de citocinina nos meios de cultivo para cada genótipo devido haver influência quanto ao nível e tipo do regulador de crescimento em questão.

Nesse sentido, várias pesquisas já foram desenvolvidas em bananeira com o intuito de verificar a ação dos níveis exógenos de citocinina, em especial a $\mathrm{N}^{6}$-benzilaminopurina (BAP) (Santana \& Alloufa, 2000; Oliveira et al., 2001; Gübbük \& Pekmezci, 2004), assim como o potencial antioxidante de algumas substâncias (Silva et al., 2001; Alloufa et al., 2002) e, desta forma, minimizar os efeitos negativos da oxidação fenólica durante o cultivo in vitro de Musa sp. Dentre os antioxidantes usados, destaca-se o carvão ativado, um componente que tem sido frequientemente adicionado aos meios de cultura de tecidos vegetais com sucesso (Van Winkle et al., 2003), mas de cujos efeitos ainda não se possui bom entendimento. Entretanto, existem considerações de que o carvão ativado promove a adsorção de hormônios (auxinas, citocininas), produtos do metabolismo de plantas (exudatos) e metabólicos tóxicos, como os compostos fenólicos (Ebert et al., 1993; Pan \& Van Standen, 1998), além de vitaminas, Fe-EDTA, íons $\mathrm{Zn}$ e $\mathrm{Cu}$, e outros componentes do meio de cultura (Johannson

\footnotetext{
${ }^{1}$ (Trabalho 191-2005). Recebido: 23-11-2005. Aceito para publicação: 18-05-2006. Trabalho realizado com apoio financeiro do Conselho Nacional de Desenvolvimento Científico e Tecnológico - CNPq.

${ }^{2}$ Eng. Agr ${ }^{\circ}$, Mestrando em Fitotecnia/UFLA, Caixa Postal 37, CEP 37200-000 Lavras-MG. E-mail: fredericohenrique @ yahoo.com.br.

${ }^{3}$ Eng. Agr ${ }^{\circ}$, Pesquisador da Embrapa Acre, Caixa Postal 321, CEP 69908-970 Rio Branco-AC. E-mail: jonny @cpafac.embrapa.br.

${ }^{4}$ Graduanda do curso de Engenharia agronômica, Universidade Federal do Acre, Rio Branco-AC. Bolsista PIBIC/CNPq/Embrapa Acre. E-mail: aparecidaalves@yahoo.com.br; janiffepoliveira@hotmail.com.
} 
TABELA 1 - Influência do carvão ativado no meio de cultura sobre as variáveis comprimento de brotações, taxa de multiplicação, oxidação, vigor e número de raízes formadas em bananeira, cv. Grand Naine. Rio Branco-AC, 2004.

\begin{tabular}{cccccc}
\hline Meio de cultura & Comprimento $\mathbf{( c m )}$ & Taxa de multiplicação & Oxidação & Vigor & $\mathbf{N}^{\circ}$. raízes \\
\hline Com carvão & $4,8 \mathrm{a}$ & $2,3 \mathrm{~b}$ & $2,1 \mathrm{a}$ & $2,4 \mathrm{a}$ & $6,1 \mathrm{a}$ \\
Sem carvão & $2,7 \mathrm{~b}$ & $3,5 \mathrm{a}$ & $2,4 \mathrm{~b}$ & $1,5 \mathrm{~b}$ & $4,3 \mathrm{~b}$ \\
\hline C.V. $(\%)$ & 13,4 & 8,4 & 7,2 & 11,1 & 9,9 \\
\hline
\end{tabular}

Médias seguidas por letras distintas dentro de cada item avaliado diferem entre si, a $5 \%$ de probabilidade, pelo teste de Tukey.

et al., 1990; Van Winkle et al., 2003).

Desta forma, os objetivos deste estudo foram avaliar os efeitos da interação entre o carvão ativado e diferentes concentrações de $\mathrm{N}^{6}$-benzilaminopurina (BAP) na multiplicação in vitro da bananeira, cv. Grand Naine (AAA).

\section{MATERIAL E MÉTODOS}

O trabalho foi conduzido no Laboratório de Cultura de Tecidos da Embrapa Acre. O material vegetal utilizado foi a cultivar Grand Naine. Como fonte de explantes, utilizou-se de mudas do tipo chifre ou chifrinho, obtidas do matrizeiro da Embrapa Acre.

Após a coleta, foi realizada a limpeza mecânica dos explantes, removendo-se parte do rizoma e do pseudocaule até o tamanho aproximado de $5 \mathrm{~cm}^{3}$. Em seguida, os propágulos foram lavados em água corrente e levados para câmara de fluxo laminar, onde se realizou a primeira desinfestação pela imersão em álcool $(70 \%)$, por cinco minutos, seguida de 20 minutos em hipoclorito de sódio (50\% da solução comercial). Após este período, os ápices foram lavados por três vezes em água destilada e esterilizada e novamente reduzidos até tamanho máximo de $1 \mathrm{~cm}^{3}$. O estabelecimento em meio de cultura foi realizado em frascos de vidro tipo "baby food" $(5,0 \mathrm{~cm}$ x 7,0 cm) com $30 \mathrm{~mL}$ de meio MS (Murashige \& Skoog, 1962), solidificado com 5 g.L $\mathrm{L}^{-1}$ de ágar.

O cultivo estabelecido foi mantido por um período de 45 dias, em sala de crescimento, na ausência de luz. Após este período, as brotações desenvolvidas foram transferidas para meios de proliferação, em frascos de $250 \mathrm{~mL}$ de capacidade e $40 \mathrm{~mL}$ de meio. Nesta etapa, foram retiradas as partes fenolizadas dos explantes, iniciando-se assim o processo de multiplicação em meio de cultura de MS. Os tratamentos foram dispostos em um esquema fatorial $2 \times 4$, constituído da presença e ausência de carvão ativado ( 0 e 3 g.L $\left.\mathrm{L}^{-1}\right)$ associado à diferentes concentrações de $\mathrm{N}^{6}$-BAP $\left(0 ; 2 ; 4\right.$ e $\left.6 \mathrm{mg} . \mathrm{L}^{-1}\right)$, num total de 8 tratamentos. O delineamento foi inteiramente casualizado, com cinco repetições e quatro explantes por parcela.

Durante a multiplicação, os materiais foram mantidos em sala de crescimento sob temperatura de $25 \pm 2{ }^{\circ} \mathrm{C}$, fotoperíodo de 16 horas e intensidade luminosa de $30 \mu \mathrm{mol} . \mathrm{m}^{-2} \mathrm{~s}^{-1}$.

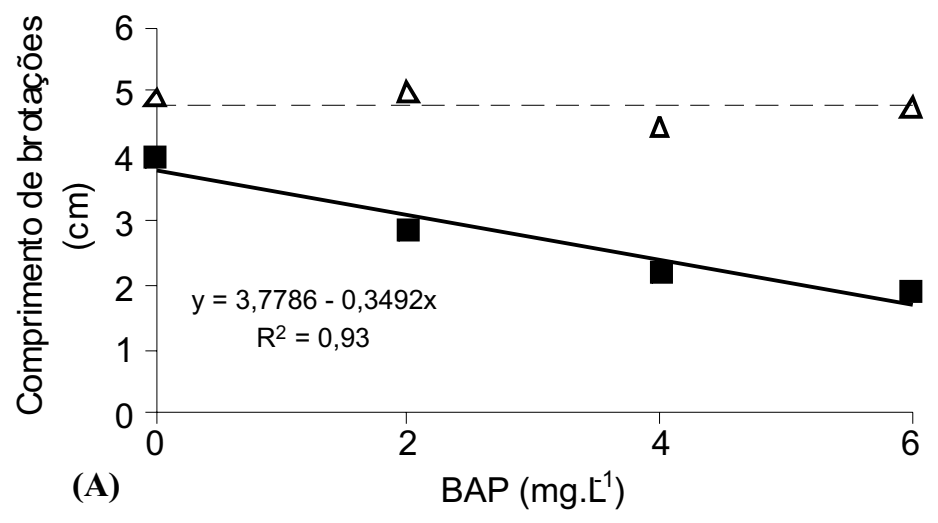

Meio sem carvão $\Delta$ Meio com carvão

FIGURA 1 - Efeito de concentrações de $\mathrm{N}^{6}$-BAP e presença e ausência de carvão ativado no meio de cultura sobre o comprimento de brotações e taxa de multiplicação em bananeira, cv. Grand Naine. Rio Branco-AC, 2004
As avaliações quanto à altura, taxa de multiplicação, vigor das brotações emitidas, grau de oxidação dos explantes e número de raízes formadas foram realizadas a cada 30 dias de cultivo, por um período de quatro subcultivos. As variáveis vigor (desenvolvimento geral) e nível de oxidação foram analisadas comparativamente entre as brotações regeneradas, ao final de cada subcultivo, por meio de uma escala de notas atribuídas arbitrariamente, que variou de 1 a 3 , significando: 1) pouco, 2) medianamente ou 3) brotações muito vigorosas (desenvolvidas)/oxidadas. Em cada subcultivo, os explantes eram limpos, retirando-se as partes fenolizadas.

Os dados foram submetidos à análise de variância e de regressão, fazendo-se a comparação das médias pelo Teste de Tukey, a $5 \%$ de probabilidade. Dados referentes à taxa de multiplicação (x) e número de raízes foram transformados segundo $(x+1)^{0,5}$.

\section{RESULTADOS E DISCUSSÃO}

Independentemente das diferentes concentrações de $\mathrm{N}^{6}$-BAP utilizadas, foi observado influência significativa da adição do carvão ativado ao meio de cultura, em todas as variáveis avaliadas. Brotações cultivadas na presença de carvão ativado apresentaram maior altura, vigor e número de raízes formadas quando comparadas àquelas cultivadas em meio de cultura, na ausência deste antioxidante. Por outro lado, a presença em meio de cultura provocou a redução da taxa de multiplicação e nível de oxidação dos explantes (Tabela 1), independentemente das concentrações de $\mathrm{N}^{6}$-BAP testadas.

Já quando se avalia a interação carvão ativado $\mathrm{x} \mathrm{N}^{6}$-BAP por meio da análise de regressão, verifica-se que, para comprimento de brotos, houve efeito negativo dos níveis de $\mathrm{N}^{6}$-BAP em meio desprovido de carvão ativado, o que foi caracterizado pela acentuada redução do comprimento à medida que se elevou a concentração desta citocinina (Figura 1a). Este fato pode ser atribuído aos efeitos do N ${ }^{6}$-BAP em quebrar a dominância apical e favorecer a emissão de novos brotos (Mok, 1994, citado por Mok et al., 2000). De acordo com Grattapaglia \& Machado (1990), o alongamento pode ser inibido pelo efeito acumulativo do regulador de crescimento presente no meio, no caso a $\mathrm{N}^{6}$-benzilaminopurina (BAP). Estudos realizados por Diniz et al. (2003) demonstraram que a adição de BAP no meio de cultura

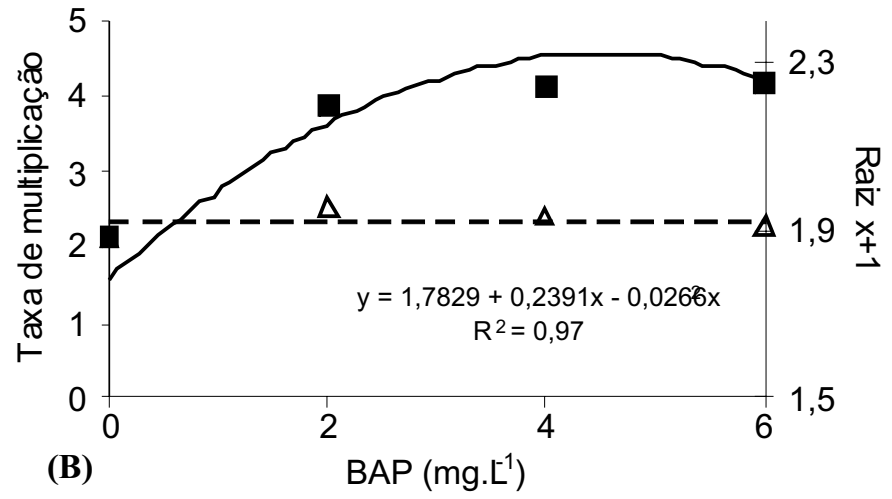

Meio sem carvão $\Delta$ Meio com carvão 

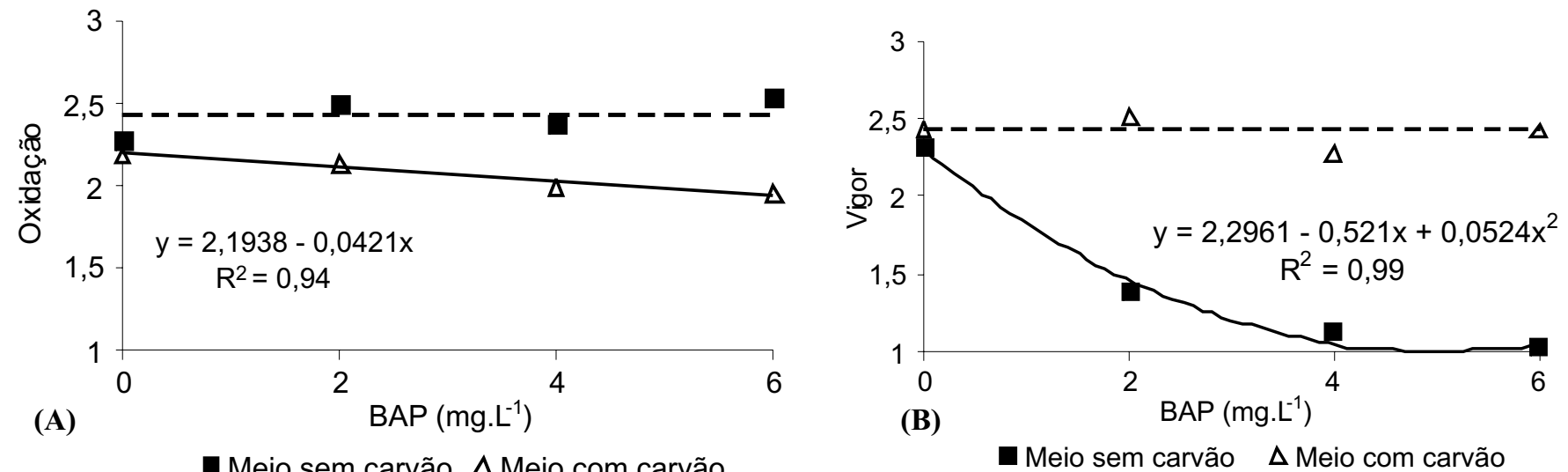

FIGURA 2 - Efeito de concentrações de $\mathrm{N}^{6}$-BAP e presença e ausência de carvão ativado no meio de cultura sobre o nível de oxidação (a) e vigor (b) em brotações de bananeira, cv. Grand Naine. Rio Branco-AC, 2004.

também causou redução no comprimento de brotações de macela. Em bananeira, Souza \& Gonçalves (1996) verificaram que, em meio de cultura sem a presença de $\mathrm{N}^{6}$-BAP, a cv. Caipira apresentou forte dominância apical, contrário aos tratamentos com doses crescentes desta citocinina. Webb et al. (1978), citados por Pan \& Van Standen (1998), relatam que o crescimento de brotos de Pinus strobus foi promovido pelo carvão ativado. Contudo, a suplementação deste meio de cultura com concentrações de $\mathrm{N}^{6}$-BAP inibiu a indução de novos brotos e a rizogênese.

Por outro lado, não foram observadas diferenças significativas para comprimento de brotações quando estas foram cultivadas em presença do carvão ativado, independentemente das concentrações de $\mathrm{N}^{6}$-BAP testadas (Figura 1a). Tais resultados se devem, muito provavelmente, ao fato de o carvão ativado adsorver reguladores de crescimento e, desta forma, reduzir ou mesmo neutralizar sua atividade. Este fato também foi observado por Buchheim et al. (1989), citados por Pullman et al. (2005), em que a combinação de carvão ativado inibiu os efeitos do ácido abscísico (ABA), com subseqüente perda de sua atividade biológica. Estes autores afirmam que o uso de carvão ativado em meio de cultura é mais recomendado quando se busca o enraizamento in vitro, alongamento de brotos, ou cultura de antera.

Para taxa de multiplicação, a adição de carvão ativado ao meio promoveu menor número de brotos por explante inicial, em média 2,3 brotos, independentemente dos níveis de $\mathrm{N}^{6}$-BAP testados, evidenciando o efeito de adsorção do $\mathrm{N}^{6}$-BAP pelo carvão ativado, uma vez que, na ausência deste antioxidante, o aumento da concentração de $\mathrm{N}^{6}$-BAP favoreceu a taxa de multiplicação, até aproximadamente $4 \mathrm{mg} . \mathrm{L}^{-1}$, a partir da qual a adição de $\mathrm{N}^{6}$-BAP ao meio não mais promoveu acréscimos significativos para esta variável (Figura 1b). Segundo Pullman et al. (2005), para que se obtenham os benefícios do carvão ativado e dos reguladores adicionados aos meios, é necessário que se eleve o nível do fitorregulador de interesse. Trabalhando com as cultivares de bananeira Pelipita e Prata Ken, Quisen (2002) verificou pequenas diferenças na capacidade proliferativa entre níveis de $\mathrm{N}^{6}$-BAP testados, levando à conclusão de que tais resultados podem estar associados à interação genótipo e citocinina. Daí a necessidade de se otimizar a cada genótipo o nível exógeno ou mesmo o tipo de citocinina a ser adicionado ao meio.

Para a variável oxidação, constatou-se efeito benéfico do carvão ativado, havendo leve redução do nível de oxidação à medida que se elevou a concentração de $\mathrm{N}^{6}$-BAP no meio. Por outro lado, em meio desprovido de carvão ativado, o nível de oxidação foi superior, não diferindo significativamente, porém, quanto às concentrações de $\mathrm{N}^{6}$-BAP (Figura 2a). Quanto ao vigor das brotações, verificou-se um comportamento quadrático descendente entre a ausência de carvão e a elevação da concentração de $\mathrm{N}^{6}$-BAP no meio. Assim, brotações cultivadas em meio livre deste antioxidante apresentaram decréscimo no vigor à medida que se elevaram os níveis desta citocinina, fato confirmado pelo maior vigor obtido na concentração de $0 \mathrm{mg} . \mathrm{L}^{-1} \mathrm{de}$ $\mathrm{N}^{6}$-BAP. Já em meio de cultura com carvão ativado, não foram verificadas diferenças significativas para esta variável, independentemente das concentrações de $\mathrm{N}^{6}$-BAP utilizadas. Porém as brotações foram mais vigorosas em comparação à adição exógena de $\mathrm{N}^{6}$-BAP em meio sem carvão (Figura $2 b$ ), levando a inferir que houve maior absorção de nutrientes pelas brotações sob a influência deste antioxidante, já que brotações cultivadas nestas condições de meio apresentaram reduzida oxidação e maior formação de raízes (Figura 3) do que aquelas cultivadas em meio de cultura desprovido de carvão ativado.

Para a característica número de raízes formadas, verificou-se que brotações cultivadas em meio desprovido de carvão ativado apresentaram decréscimo no número de raízes à medida que se elevou a concentração de $\mathrm{N}^{6}$-BAP, enquanto na concentração de $0 \mathrm{mg} . \mathrm{L}^{-1}$ a média foi de 6 raízes por explante, e na concentração de $6 \mathrm{mg} . \mathrm{L}^{-1}$ esse número foi próximo a 2,3 (Figura 3). Esse fato confirma a teoria de que as citocininas inibem ou atrasam a formação de raízes (Ben-Jaacov et al., 1991). Resultados similares foram obtidos por Diniz et al. (2003), que observaram redução no número de explantes de macela com raízes, em meio com elevadas concentrações de $\mathrm{N}^{6}$-BAP.

Entretanto, a suplementação do meio com carvão ativado favoreceu o enraizamento das brotações, independentemente das concentrações de $\mathrm{N}^{6}$-BAP testadas (Figura 3). Grattapaglia \& Machado (1998) reportam que o carvão simula a condição de escuro na qual as raízes normalmente se desenvolvem melhor, além de possuir efeito diluidor, retendo parte de todos os elementos que compõem o meio, absorvendo compostos fenólicos inibidores do enraizamento. Cronauer \& Krikorian (1984), comparando o efeito da adição de ANA, AIA e AIB ao meio de cultura em presença de $0,025 \%$ de carvão ativado,

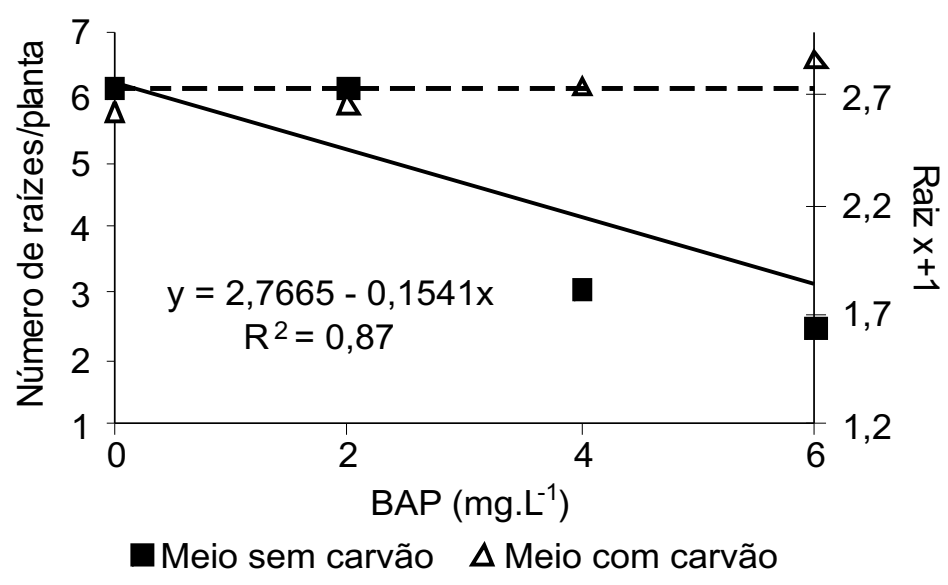

FIGURA 3 - Efeito de concentrações de N ${ }^{6}$-BAP e presença e ausência de carvão ativado no meio de cultura sobre o número de raízes formadas em bananeira, cv. Grand Naine. Rio Branco-AC, 2004. 
não observaram diferenças destes sobre o enraizamento in vitro de Musa. Gübbük \& Pekmezci (2004) também concluíram ser desnecessária a adição de fitorreguladores (ANA e AIB) no meio MS para o enraizamento de Musa spp., sugerindo que apenas a adição de carvão ativado é eficiente no enraizamento. Villegas (1990), citado por Calvete et al. (2002), verificou que a utilização do carvão ativado causou efeito benéfico na estimulação da rizogênese in vitro de morangueiro em relação ao tratamento à testemunha (ausência de carvão ativado). Santana et al. (2005), avaliando a influência do AIB e do carvão ativado em brotações de Annona glabra, verificaram efeitos positivos da adição do carvão sobre o número de raízes, número de raízes secundárias, comprimento da maior raiz, percentagem de enraizamento e peso seco das raízes, além de um efeito altamente significativo sobre o crescimento e o desenvolvimento da parte aérea das microplantas.

\section{CONCLUSÕES}

1. A adição de carvão ativado ao meio de cultura MS reduz significativamente a taxa de multiplicação e o nível de oxidação de brotações de bananeira, cultivar Grande Naine.

2. Brotações mais altas, vigorosas e com maior número de raízes são obtidas em meio MS acrescido de carvão ativado.

3. Concentrações de até $6 \mathrm{mg} . \mathrm{L}^{-1}$ de $\mathrm{N}^{6}$-BAP em meio de cultura com carvão ativado não exercem nenhuma influência sobre comprimento, taxa de multiplicação, oxidação, vigor e número de raízes em bananeira, cv. Grande Naine.

\section{REFERÊNCIAS}

ALLOUFA, M.A.I.; MACÊDO, C.E.C. de; BARROSO, P.A.V.; BARBALHO, A.D.; OLIVEIRA, C.H.B. de. Avaliação de dois agentes antioxidantes no estabelecimento in vitro de inflorescências de bananeira (Musa spp). Ciência e Agrotecnologia, Lavras, v.26, n.5, p.1092-1096, 2002.

ANDRADE, M.W.; LUZ, J.M.Q.; LACERDA, A.S. Micropropagação da aroeira (Myracroduon urundeuva Fr. All.). Ciência e Agrotecnologia, Lavras, v.24, n.1, p.174-180, 2000.

ARIAS, O. Commercial micropropagation of banana. In.: BIOTECHNOLOGY applications for banana and plantain improvement. San Jose, Costa Rica: Inibap, 1992. p.139-142.

BEN-JAACOV, J.; ACKERMAN, A.; TAL, E.; JACOBS, G. Vegetative propagation of Alberta magna by tissue culture and grafting. HortScience, Alexandria, v.26, n.2, p. 74-75, 1991.

CALVETE, E.O.; KÄMPF ,A.N.; SUZIN, M. Concentração de sacarose no enraizamento in vitro de morangueiro. Horticultura Brasileira, Brasília, v. 20, n.2, p. 186-191, jun 2002.

CRONAUER, S.S.; KRIKORIAN, A.D. Rapid multiplication of bananas and plantains by in vitro shoot tip culture. HortScience, Alexandria, v.19, p.234-235, 1984.

DINIZ, J.D.N.; ALMEIDA, J.L.; TEIXEIRA, A.L. de A.; GOMES, E.S.; HERNANDEZ, F.F.F. Ácido giberélico $\left(\mathrm{GA}_{3}\right)$ e 6-Benzilaminopurina (BAP) no crescimento in vitro de Macela [Egletes viscosa (L.) Less.]. Ciência e Agrotecnologia, Lavras, v.27, n.4, p.934-938, 2003.

EBERT, A.; TAYLOR, F.; BLAKE, J. Changes of 6-benzylaminopurine and 2,4-dichlorophenoxyacetic acid concentrations in plant tissue culture media in the presence of activated charcoal. Plant Cell, Tissue and Organ Culture, Dordrech, v.33, p.157-162, 1993.

GRATTAPAGLIA, D.; MACHADO, M.A. Micropropagação. In.: TORRES, A.C.; CALDAS, L.S. Técnicas e aplicações da cultura de tecidos de plantas. Brasília: Embrapa-CNPH, 1990. p.99-169.
GRATTAPAGLIA, D.; MACHADO, M.A. Micropropagação. In.: TORRES, A.C.; CALDAS, L.S.; BUSO, J.A. Cultura de tecidos e transformação genética de plantas. Brasília: Embrapa/SPI/CNPH, 1998. v.1, p. 183-260.

GÜBBÜK, H.; PEKMEZCI, M. In Vitro Propagation of Some New Banana Types (Musa spp.). Turkish Journal of Agriculture and Forestry, Istambul, v.28, p.355-361, 2004.

JOHANNSON, L.; CALLEBERG, E.; GEDIN, A. Correlations between activated carbon, Fe-EDTA and other organic media ingredients in cultured anthres of Anemone canadensis. Physiologia Plantarum, Copenhagem, v.80, p.243-249, 1990.

MOK, M.C.; MARTIN, R.C.; MOK, D.W.S. Cytokinins: biosynthesis, metabolism and perception. In Vitro Cellular \& Developmental Biology Plant, Columbia, v.36, p.102-107; 2000.

MURASHIGE, T.; SKOOG F.A. Revised medium for rapid growth and bio assays with tobacco tissue cultures. Physiologia Plantarum, Copenhagem, v.15, p.473-497, 1962

OLIVEIRA, R.P. de; SILVEIRA, D.G.; SILVA, S.O. Concentração de BAP e a eficiência de micropropagação de bananeira tetraplóide (Grupo AAAB). Scientia Agrícola, Piracicaba, v.58, n.1, p.73-78, 2001.

PAN, J.J.; VAN STADEN, J. The use of charcoal in in vitro culture - a review. Plant Growth Regulators, The Hague, v.26, p.155-163, 1998.

PULLMAN, G.S.; GUPTA, P.K.; TIMMIS, R.; CARPENTER, C.; KREITINGER, M.; WELTY, E. Improved Norway spruce somatic embryo development through the use of abscisic acid combined with activated carbon. Plant Cell Report, New York, v.24, p.271279, 2005

QUISEN, R.C. Multiplicação in vitro de bananeira cv. Pelipita (ABB) e cv. Prata Ken (AAAB). In: XVII CONGRESSO BRASILEIRO DE FRUTICULTURA, 17., 2002, Belém-PA. Anais... (CD-ROM).

SANTANA, R.A. de S.; ALLOUFA, M.A.I. Propagação in vitro da bananeira (Musa sp) cultivar Pacovan: efeito de várias concentrações de BAP. Revista Brasileira de Fruticultura, Jaboticabal, v.22, n.3, p. 481-482, dez. 2000.

SANTANA, J.R.F.; BRITO, A.L.; PAIVA, R. Influência do AIB e do carvão ativado no enraizamento, crescimento e desenvolvimento de microplantas de Annona glabra L. In: CONGRESSO BRASILEIRO DE OLERICULTURA, 45., CONGRESSO BRASILEIRO DE FLORICULTURA E PLANTAS ORNAMENTAIS, 15., CONGRESSO BRASILEIRODECULTURA DE TECIDOS DE PLANTAS, 2., 2005, Fortaleza. Anais... (CDROM).

SATO, A.Y.; DIAS, H.C.T.; ANDRADE, L.A. et al. Micropropagação de Celtis sp.: controle da contaminação e oxidação. Cerne, Lavras, v.7, n.2, p.117-123, 2001

SILVA, K.M. da; OLIVEIRA, R.P. de; ARAÚJO, F.P. de; SILVA, V.C. da. Utilização de antioxidantes na micropropagação de bananeira cv. Pioneira. Magistra, Cruz das Almas, v.13, n. 1, 2001.

SOUZA, G.M.; GONÇALVES, A. N. Otimização de meio de cultura para a bananeira (Musa cavendishii L.). Scientia Agricola, Piracicaba, v.53, n.1, p.51-59, 1996.

VAN WINKLE, S.; JOHNSON, S.; PULLMAN, G.S.The impact of gelrite and activated carbon on the elemental composition of plant tissue culture media. Plant Cell Report, New York, v.21, p.1175-1182, 2003. 